\title{
Piloting Strategies in Translating Adjective
}

\author{
Nur Hasyim ${ }^{1}$ \\ ${ }^{1}$ Lecturer of Business Administration in Politeknik Negeri Jakarta \\ Jalan Prof. DR. G. A. Siwabessy, Kecamatan Beji, Depok, Jawa Barat 16424 \\ Corresponding author/E-mail: nur.hasyim@akuntansi.pnj.ac.id
}

\begin{abstract}
Parts of speech are important knowledge that needs to be known in the learning language unit to find out the appropriate meaning. Parts of speech indicate the function of the word in forming the meaning within the sentence. This research investigates the translation model of emotional intelligence terms in root word and derivative, especially in adjective type as piloting strategies in translating adjective. The research objectives are (i) to construct a translation model of translating adjectives, (ii) to describe the adjective translation model, and (iii) to describe the way to use the model. The study was using a research development approach. A model was a product of the translation stage based on translation techniques in producing good translation quality. The research was developed based on the research conducted by Nur Hasyim (2019) about "The Translation Analysis of Emotional Intelligence Terms on the book entitled Working with Emotional Intelligence by Daniel Goleman (2019)". The substance of the model was based on proposed translation techniques such as establishedequivalent, transposition, modulation, or borrowing. Those techniques are the considerable techniques that can be used to navigate in translating adjectives to obtain good translation quality.
\end{abstract}

Keywords - Adjective, Emotional intelligence, Developmental research, Piloting strategies, Translation model, Translation quality.

\section{INTRODUCTION}

$\mathrm{T}$ ranslation is complicated process in finding out appropriate meaning and message in target text. The complexity is represented in making decision. That's why decision-making process is not easy. It needs a number of skills and competences. Competence is a system which need to be mastered by someone to do special things [1]. As in other professions, translation also requires certain competences [2] [3]. Translation actually is complicated process in not only rendering the source text into target text but also how to transfer the 'feeling' which want to express by the original writer/author. In addition, translation should cover not only grammatical aspect but also contextual aspect. To conclude, translation process needs two crucial things, competencies and decision-making process.

Competencies in translation are measured if a translator able to run his/her duty in finding appropriate function of translation product. If they run their duty well, they will be able to decide the decision well also. By mastering this, they will be able to decide the translation of certain word, terms, and sentence structure well to be used in their translation. The second things which influence the process of making decision is reader of target text. Commonly, translation text is conveyed for specific reader and this case needs to be considered by translator to consider the diction, terms, and sentence structure which are suitable with the reader of target text. Common problems in translating are about equivalence. Equivalence is viewed as fundamental problem in translation [4]; [5]; [6]; [7]; [8]; and it is understood that same equivalence effect in target text is emphasized [9].

Research on equivalence in translation is also done in many aspects, including by using different approach, such as culture insight [10] [11]; discourse analysis and Systemic Functional Linguistics [12] [13] [14] [15]. The equivalence can be found in every language unit such as equivalence at word level, above word level, 
grammatical equivalence, textual equivalence, and pragmatic equivalence. [16]. Others, the classification of equivalence can be identified as formal equivalence and textual equivalence [6] . Again, main purpose of translation operates not only with sentences in grammatical layer but also with utterances or message, especially in written text [9] . Based on the above discussion, it can be outlined that there are many aspects and problems trigger in translation process. So, the prototypical translation strategies can be made to help a translator translates the text. But it is imperative to note that the notion of strategies basically different with technique in translation. [17] differentiated the term of strategy and technique based on the logic that strategy takes place in the translator's mind (internal memory system). It means that while a translator may encounter translation problems, he or she should quickly decide what have to do next to solve those problems. Strategies are the procedures (conscious or unconscious, verbal or nonverbal used by the translator to solve problems that emerge when carrying out the translation process with a particular objective in mind. In other words, the strategy is process-oriented, while the decision in choosing the translation technique is product-oriented after using proper strategy in certain problems.

Strategies can be represented by using a particular translation technique in solving the problems. Thus, to solve those problems, a translator can apply translation techniques. In other words, the technique is product-oriented. The translation techniques are in micro level. So, it should be distinguished between the technique and strategy chosen by the translator. It is known that the way to translate a specific terminology can be a word or phrase which can be a noun, verb, or adjective. These are micro level in linguistic unit, so choosing of appropriate translation technique which is a tool for analyzing the translation based on the micro unit need to be researched. This due to one characteristic of translation technique is that the translation techniques are in micro level [17].

This research development is the small part of the dissertation which had been conducted by the researcher. Based on the preliminary study in the first year, the research had found out the pattern of translation technique used to translate certain pattern of word classes. The dominant techniques used are established equivalent, transposition, modulation and borrowing which have significant improvement of translation quality. Started from that tentative findings, a prototype model of translation by using certain technique to obtain better translation quality was made. This prototype model was made to use in translation process between English into Indonesia and it was examined in second year (Hasyim, 2018). Based on the test of prototype model of translation, it can be concluded that the translation model has some characteristics. At least, the translation model has five main characteristics. First, the model can be used in micro structure of linguistic unit such as word level in root word and derivative word, especially in translating one of the unit translation (UT) (adjective) which has many types of affixes. Second, it related with proposed translation technique which is parallel with root word and derivational process. Third, it is contextually used. Fourth, each change of word class has certain recommended translation technique. The last one, it is applicable by using translation quality assessment drawn by [18] which is correlated with accuracy, acceptability, and readability.

In the second year of the research, globally, it is found 56 data of adjective class classified as emotional intelligence terms in root word. While there are 174 data represents derivative words of adjective one. But they were small part of big data in the research. There were found several translation techniques used in translating emotional intelligence terms especially adjective class either root word and derivative word. In translating root word of adjective, found established equivalent, transposition, modulation, discursive creation, pure borrowing, addition, deletion, literal translation and implicitation. In translating derivative word of adjective, found established equivalent, transposition, modulation, discursive creation, addition, literal, pure borrowing, naturalized borrowing, deletion, description, variation, generalization. Each of them brings different score quality either good impact or bad impact that should be considered by translator(s).

The translation quality in translating root word of adjective was 2.90 by accuracy is 2.89 , acceptability is 2.91 and readability is 2.92 . It can be said that the translation quality is good. While, the second translation quality in translating derivative word of adjective was higher than translating adjective in root word. The score distribution was obtained 2.97 by accuracy is 2.97 , acceptability is 2.97, readability is 2.98 . Dominantly, it is caused by several technique such as established equivalent, transposition, modulation 
and sometimes pure borrowing in translating adjective.

There are lots number of translation researches done by many translation scholars which can be reviewed as foundation to develop this research. The results above were supported by some scholars who researched about the translation technique and its translation quality in case study approach. The translation aspect which they research is different each other. Among of them tried to research translation quality of film subtitle (word, phrase, clause, sentence as linguistic data) [19] [20]); cultural terms [21]; [22]; technical terms on legal document translation [23]; economics and financial management terms [24] and engineering terms [25] and research terms [26]. Most of them agree that there are certain techniques which can give positive impact on translation quality such as established equivalent, transposition, modulation, borrowing, sometimes imlicitation and explicitation. Again, they believe that there are also certain techniques which can give negative impact on translation quality such as literal translation, addition, deletion, and discursive creation.

Besides case study as resource for research review, there are also some other researches deals with translation model such as translation assessment quality development [27]; clarification of translation strategy and translation technique [17]; syntactic, semantic and pragmatic approach [7] ; textual typology, formal correspondence, thematic coherence, reference cohesion, pragmatic equivalence and lexico-syntactic properties [28]. Those models basically tried to seek equivalence as a core point in translation.

The researches about the translation modelling has been developed by many translation scholars. Some research had been considered to be reference in making this continuative research development approach such as [29] examined the integrated methodology of translation model - translation analysis - translation strategy; translation technical process [30]; translation quality assessment model [27]; cognitive modelling in understanding translation process [31]. Based on the review of model developed above, this research tries to develop a framework as prototype that can be employed to for translation process by identifying linguistic unit which want to translate and identifying the morphological process to define proper meaning.
It is focusing on how to translate adjective in root word and derivative word by using proposed technique based on. The prototype model composed from translation quality assessment [18], translation technique [17] and morphological approach in traditional grammar. To examine the prototype, the researcher asked some post-graduate students in State Polytechnic of Jakarta to translate some documents by using proposed-translation technique. The techniques are establishedequivalent, transposition, modulation, and/or borrowing translation. Based on the operational procedure which has been explained by the researcher, the test-taker tried to use the prototype. According to the test-takers, their ability in translating was improving. The improvement was approximately $30 \%$ in rate after using the proposed-technique. After examining the prototype, it was revised based on suggestion from the experts on second Focus Group Discussion (FGD) and review to the previous researches. In conclusion, the researcher made translation model. The model was technique-based translation model.

Over all, this developmental research aims to classify some general patterns in the emergence of translation problems especially in translating adjective in root word and derivative word. As well as, this study also provides the 'piloting' process which is represented in translation model to use translation technique properly in translating adjective. From a practical standpoint, the research describes and provides characteristic features of how to translate adjective which is corresponding translation problems. In addition, the research offers translation model including translation strategies to help the translator restructures text by piloting efficient translation process. The research results may be applied by translators in pertinent areas of specialization and by translator and interpreter as well (including developing curricula and courses in translation and interpreting, syntax, semantics, and even translation of special texts).

\section{LITERATURE REVIEW}

As stated in the beginning above, translation involved complicated process. Due to this, the role of translator skills and competence has been pursued. Many translator scholars tried to define what the translation is. [9] with his meaning equivalence in translation; [32].with his language style effect. [33] proposed that translation need to do three steps which briefly can be mentioned such 
as understanding the grammatical structure (including context of situation and culture of source text; analyzing source text; re-expressing the meaning appropriately in target language). Similarly, [34] stated that translation process at least, by doing three procedures. They are analyzing the text; transferring; and restructuring according to target language. [35]more explicitly described that translation as replacement of textual material in one language by equivalent textual material in another language.

Based on argumentation deals with translation above, it can be concluded that in translation process is required certain competences not only bilingual competence but also another competence. According to Merriam Webster Dictionary, competence is the quality or state of being functionally adequate or of having sufficient knowledge, judgment, skill, or strength (as for a particular duty or in a particular respect). [1] stated that translation competence is defined as a system functioned as foundation and skills which are required by someone to be able to translate. Moreover, [36], translation competence includes the set of knowledge and skills possessed by the translator so as to perform a translation. In particular, translation competence consists of subcompetences. Specifically, [37] classified five parameters in translation competences such as linguistic competence, textual competence, field competence, cultural competence, and transfer competence. It can be called as 'terms and condition' that have to be required by a translator in order to be able to translate. It means, he or she has to master morphological system, lexical and grammatical of both languages. As a result, competence is needed to obtain good quality translation of the text. In this research, researchers wanted to focus onto morphological system as one of the sub-competences that must be had by translator in translating a word. To sum up, competence is the integration and combination of numerous types of abilities and skills not only to know-what but also have to be able to know-why and to know-how.

Knowledge of a language includes knowledge between relationship of the form and meaning of words. For instance, the words power, powerful, effective, positive, super, superior, optimistic, pessimistic, oafish, and sympathetic show as adjectives in English. The field of linguistics that cover the variation of word based on its formation and derivational process is called morphology.
Morphology is one of the branch in linguistics studied the forms of the words [38]. The existence of such patterns also implies that word may have an internal constituent structure. It can be root word and derivative word. Root word is the morpheme at the core of the word which affixes can be added, meanwhile, the derivative or derivation can be shaped from affixation process so it produces the new word which has the different class and produces the compound word. The affixation process is also able to shape the new word such as the word with reduplication. The derivational process can be found in many daily texts such as intelligent, intelligence, able, ability, fail, failure, risk, risky, support (verb), support (noun), and so forth. It can be added by some affixations either prefix such as il-, ir-, un-, im-, in-, dis-, or suffix such as -ment, -ness, -ity, -ify, -ize, -ly, -ation, -ion, -al, -s, -ence, -ance, and so forth. Each of them represents noun marker, adjective marker, verb marker, and adverbial marker.

By knowing those above, it will be benefit for translator in translating a word such as adjective or noun or verb in English by identifying the change of form that implies to change of meaning. So, it will make easier to translate. But it needs to remember that this is not easy task due to rigid process including pay attention on every single context.

After able to identify grammatically and contextually, translation techniques can be employed to find out the closer meaning into target text. It can be represented as translation result after the translator analyzes and classifies the linguistic units such as morpheme and word analysis to knowing the word class as micro unit. In other words, translation technique can be said as realization of making decision process and the result can be seen in translation quality. There are 18 translation techniques proposed by Molina and . Each translation technique which is used will give different impact toward the translation quality which can be seen from three aspects (accuracy, acceptability, and readability) [18]. Accuracy means the text in source text must be transferred accurately. Acceptability means the translation must be transferred in line culturally and grammatically into target text. Further, the readability means the degree of readable, it means that the translation result as possible as to understand easily into target text by target readers. 


\section{METHOD}

This research was conducted by using development research paradigm. The research is used to obtain the certain product, in translation model for translating adjective as well as to obtain optimum translation quality score. Generally, this research is three-year-research scheme and consists of five steps.

The research scheme in the first year, the researcher tried to 1) classifying morphological structure based on root word and derivative word of emotional intelligence terms; 2) classifying translation techniques which were used in translating adjective of emotional intelligence terms; 3) classifying translation quality based on translation techniques by conducting first FGD.

The research scheme in the second year, the researcher tried to constructing prototype model by conducting second FGD to test strength and weaknesses of the prototype. To test and look for the prototype model effectivity, the researcher conducted testing and training the prototype model to the students in State Jakarta Polytechnic. Then, the researcher evaluated the result to be revised after knowing the strength and weakness by conducting third FGD.

The research scheme in the third year after revising prototype model, the researcher tried to constructing and developing the model and testing the translation model to translate the adjective emotional intelligence terms based on morphological structure either in root word and derivative words. In making the model, the researcher reviewed the previous results and steps to obtain the product seems like piloting strategies in translating adjective of emotional intelligence terms.

In the first (2018) and second (2019)-year research, the research data were all information which can support the constructing of prototype model. The technique of collecting data was conducting the direct observation. Direct observation here was analyzed by qualitative data analysis which included: (1) domain analysis, (2) taxonomic analysis, (3) compound analysis, (4) cultural themes analysis.

Next, in the third-year research (2019-2020), the research conducted the direct observation by making and testing the prototype model and conducting several times of FGD with translation experts. In testing prototype model, the research used the students in Jakarta State Polytechnic.

\section{RESULT AND DISCUSSION}

\section{Translation Techniques and Quality in Adjective Root Word}

The final score of the translation quality of adjective root word in emotional intelligence terms is 2.90 and 2.97 for derivative one. This score means that the translation result is accurate, acceptable, and high readability. Thus, the researcher synthesizes tentative result to design translation prototype dealing with those technique which are found. The translation technique can be seen in the following chart of figure 1 :

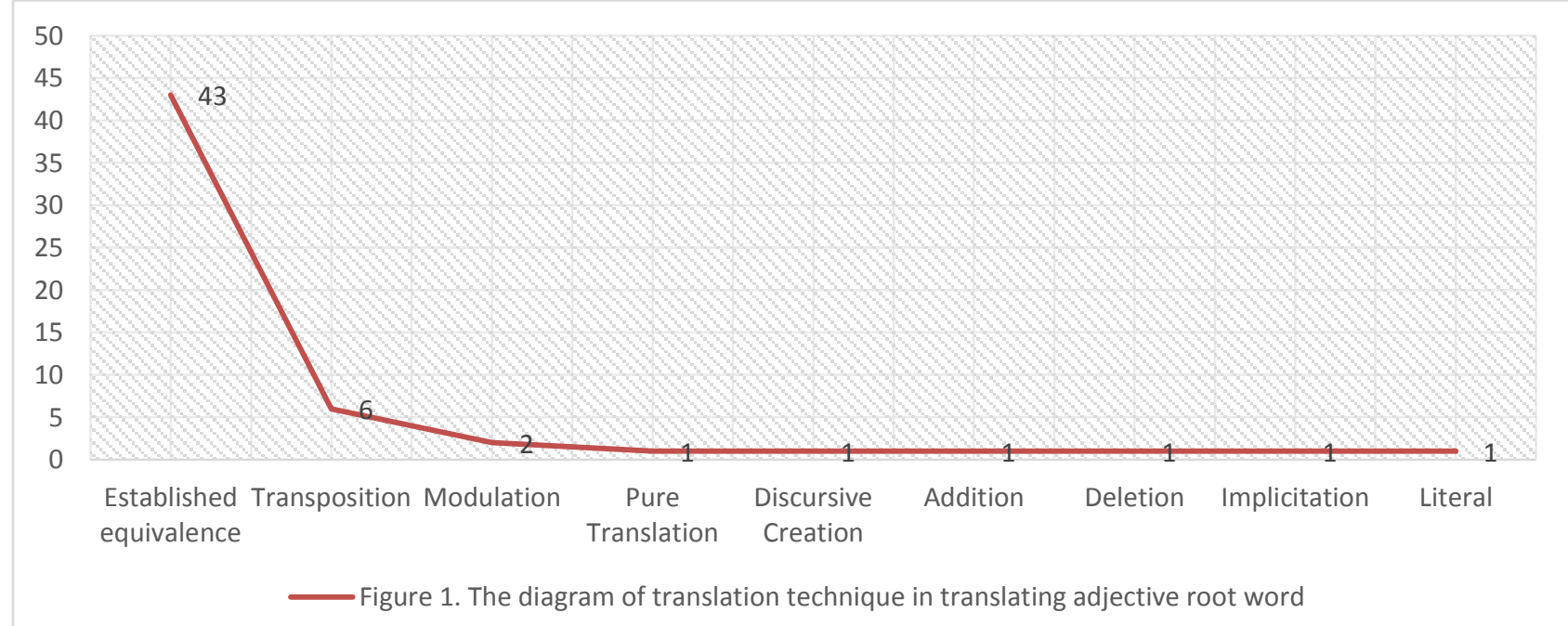

Figure 1. The Diagram of Translation Technique in Translating Adjective Root Word 
As seen in the graphic above, it can be seen that there are nine translation techniques which influenced translation quality in translating the emotional intelligence terms in adjective form. The translation techniques mostly used in translating adjective root words are established equivalence (43 data or $74 \%$ ), transposition (6 data or $10 \%)$, modulation ( 2 data or $4 \%$ ), discursive creation (1 data or $2 \%)$, pure borrowing (1 data or $2 \%$ ), addition (1 data or $2 \%$ ), deletion (1 data or $2 \%$ ), implicitation (1 data or $2 \%$ ) and literal translation (1 data or 2\%). To compare the translation quality in translating adjective derivative word, it can be seen in the following chart figure 2:

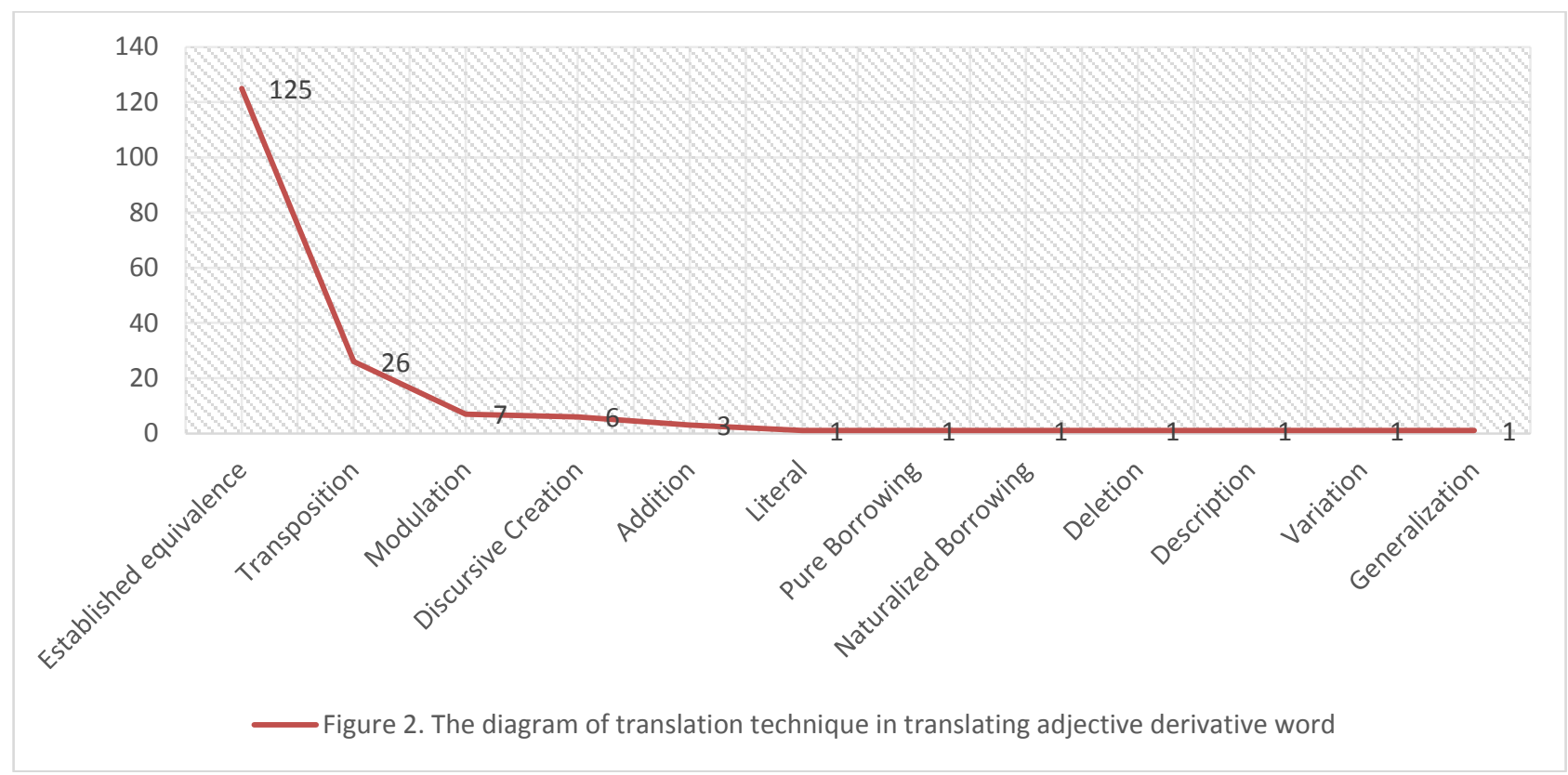

Figure 2. The Diagram of Translation Technique in Translating Adjective Derivative Word

The translation techniques mostly used in translating adjective root words are established, equivalence (125 data or $73 \%$ ), transposition (26 data or $16 \%)$, modulation (7 data or $4 \%$ ), discursive creation (6 data or $3 \%$ ), addition (3 data or $2 \%$ ), literal translation (1 data or $0.5 \%$ ), pure borrowing (1 data or 2\%), naturalized-borrowing (1 data or $0.5 \%$ ), deletion ( 1 data or $0.5 \%$ ), description (1 data or $0.5 \%$ ) and variation (1 data or $0.5 \%$ ).

Based on the results above, it can be known that there are several translation techniques which influence the translation quality. For translating adjective in root word, the most influencing translation technique is established equivalent. The next rank translation techniques are transposition and modulation which are the most considerable techniques and obtain good impact to the translation quality, especially in accuracy.

Established equivalent is a technique which uses a term or expression recognized by dictionaries or language in use as an equivalent in the TL [17]. While transposition is translation technique used to change a grammatical category since the different grammatical rule between ST and TT. Transposition can be divided into two groups, they are obligatory caused by a shift of word class, i.e., verb for noun, noun for preposition. The second one is optional. It means that the translator may change grammatical category or not. Again, modulation is translation technique used to change the point of view, focus or cognitive category in relation to the ST; it can be lexical or structural. The last technique used is borrowing which give good impact on accuracy, acceptability, and readability. Borrowing is technique used to take a word or expression straight from another language. It can be pure (without any change), e.g., to use the English word lobby translated into Indonesian lobi [17].

Differently, [6] stated the shift in translation called by translation shift and [39] stated the shift in translation called by transposition. For example found in this research, the word smart (adjective root word) translated into kepandaian (noun derivative word) in Indonesia. Again, the word immune (adjective root word) translated into kekebalan (noun) derivative word). Two examples 
above can be drawn the translation is shifthing which adjective root word in ST translated to be nomina in TT.

Next, the translation result by using modulation such as worse translated into gagal meanwhile the meaning of worse is poorer quality or lower standard; less good or less unpleasant [40]. The word gagal and worse actually are totally different. Gagal is fail in English which can be considered as noun or verb. If it is noun, fail (gagal) is the result of an exam in which a person is not successful or not succeed (verb). This translator decision tries to change original point of view. Based on the meaning and syntax, sometimes it will be good and sometimes it will be bad. Actually, they have similarities in using transposition or modulation. As known that transposition is a shift between grammatical categories while modulation is a shift in cognitive categories.

Those findings are supported by some researchers that conclude that transposition and modulation may use since its effect on target meaning. Sometimes it will be appropriate and sometimes it will not [41]. In certain situation while the translator finds problems in equivalence, these two techniques are recommended to use because there is no single language which has identical grammatical rule [42]. Even, Hoed, (2006) said that one of the effective strategy to solve problems in equivalence is using shift either structurally (transposition) or semantically (meaning) which known as modulation.

Most of the translation scholars attached special important translation techniques to the translator's ability in solving the translation problems. The most considerable translation techniques which can obtain good translation quality are established equivalent and transposition [12] [22] [24] [25] [26] [43]. The kinds of problems in translation are vary. The translation problems can be in micro level and macro level. Before deciding the translation technique, a translator should be able to identify the unit of language that is going to translate in navigating to choose the suitable strategy and translation technique. The translator should understand which level they want to translate whether micro level or macro one. This is suitable with what Molina and [17] said that the use of translation technique has five characteristics. Those are 1) affecting the result of the translation; 2) classified by comparison with the original; 3) affecting micro-units of text: 4) nature discursive and contextual; 5) functional.

Back to the research findings above, one of the translation technique used is established equivalent. The translation quality score can be considered good by this technique in three aspect translation quality (accuracy, acceptability, and readability). Established-equivalent is used to obtain a term or expression recognized by dictionaries or language in use as an equivalent in the TL context. In context of adjective root words and derivative one, for example, the word sullen in English is translated murung in Indonesia. The word smooth translated lancar in Indonesia.

In adjective derivative word, the word hierarchical translated hierarkis into Indonesian. The word individualistic translated into individualistis. The word hierarchical obtained from suffix $-i c$ and cal, while the word individualistic obtained from the word individu added suffix $-a l$, -ist, and $-i c$. Due to this, the translator used established equivalent which the translated words can be recognized and common in target language. The most of translation scholars and researchers agree and support that this is the most considerable technique to use is established equivalent [22] [24] [25] [26] [44] Deals with borrowing technique, if the aim of a translation method is target text oriented version, borrowing will be one of the most frequently used translation techniques [17]

\section{Translation Prototype Model (Translation Technique and Translation Quality)}

In this part is provided the translation model after analyzing morphological structure of adjective either in root word or derivative word, translation techniques and translation quality. The model can be used for the (future) translators as a recommendation. The nature of the model is navigating or piloting the translator(s) to choose recommended-translation techniques. The model divided into two types. They are model for adjective root word translation of emotional intelligence term and model for adjective derivative word translation 


\section{The Prototype of Translating Adjective in Root Word}

The prototype of translation technique is designed in mapping how should a translator use proper technique in order to produce good translation quality. This prototype is made based on the previous findings about translation technique proposed by [17] content analysis by conducting FGD with the translation experts and considering the literature and relevant research reviews. After all stages above conducted, the research has obtained the prototype of translation technique. The prototype is as follows:

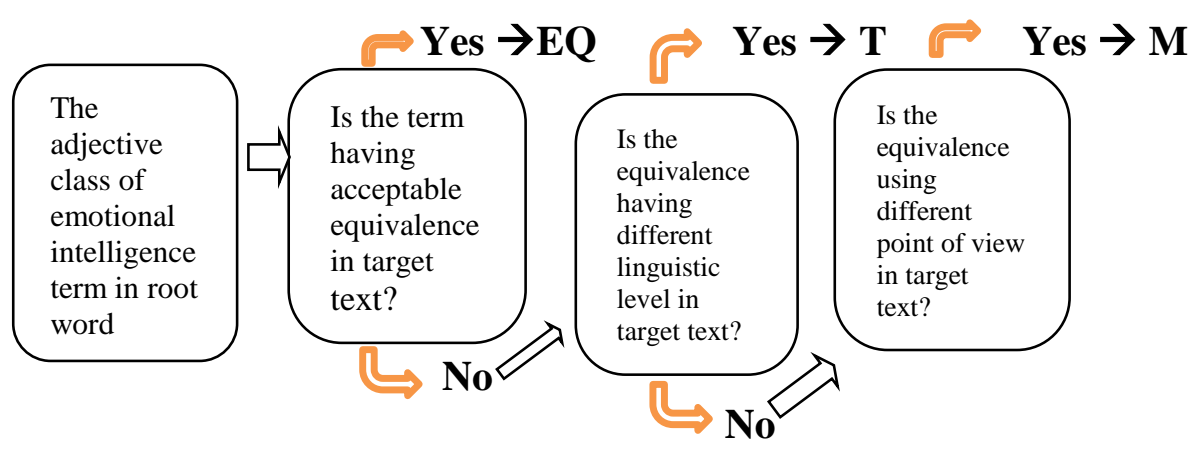

Note: $\mathrm{EQ}=$ established-equivalent; $\mathrm{T}=$ Transposition; $\mathrm{M}=$ Modulation;

Figure 3. The Scheme of Translation Prototype in Translating Root Word Adjective

Here the following prototype in translating derivative word adjective:

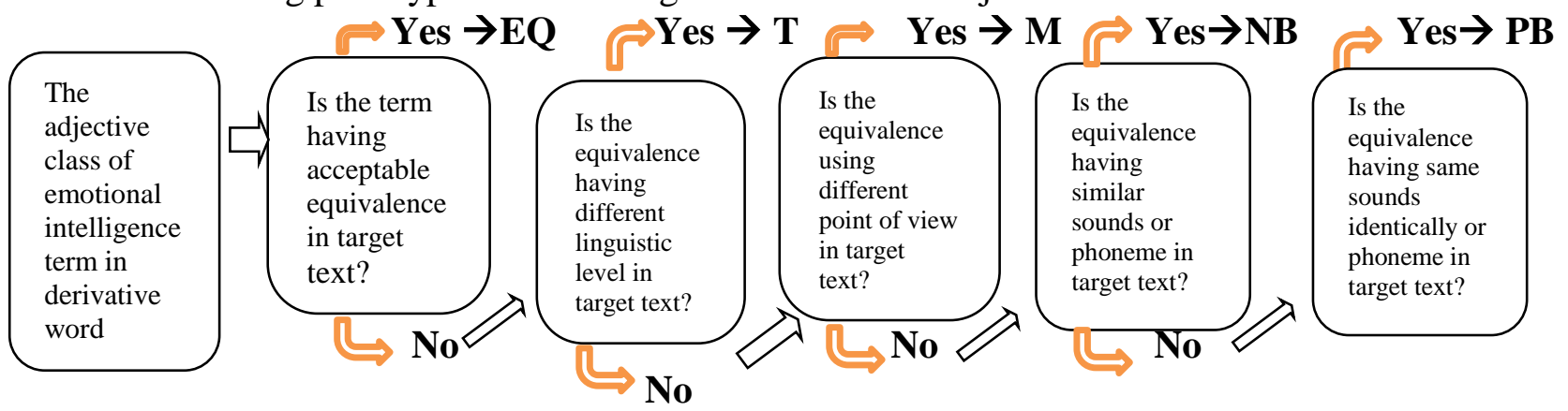

Note: $\mathrm{EQ}=$ Established-equivalent; $\mathrm{T}=$ Transposition; $\mathrm{M}=$ Modulation; $\mathrm{NB}=$ Naturalized Borrowing; $\mathrm{PB}=$ Pure Borrowing

Figure 4. The Scheme of Translation Prototype in Translating Derivative Word of Adjective

As seen in the figure above, it is known that there are four key question before a translator translates certain document. Beginning from knowing the linguistic unit which is going to be translated for the first stage. Second, considering the acceptability in the target language. Third, considering the different linguistic level which may be caused by different grammatical rule. Fourth, considering the different point of view which may be caused by different culture norm. The last is considering the sounds whether certain word has similar sound. Again, in the translation techniques provided based on the scheme of prototype above are only four techniques. The translation techniques are established-equivalent, transposition, modulation, and borrowing (naturalized and/or pure). These techniques indicated to the option for using certain technique based on the characteristic of the text which is going to be translated. The characteristics as can be seen at the previous explanation above as preliminary guidance before translating the document. In addition, every single characteristic of the translation question (read: indicator) provided two answers of the question before decided to move the other stage. If the answer is yes, a translator can use the recommended technique. If the answer is no, a translator will be directed to move to the next question until the alternatives has been tried by the translator.

This provision of translation techniques is taken from the literature review and considering the previous related research reviews. Many 
researchers who try to elaborate and categorize the translation technique agree that certain translation technique will be good or bad while they are using. It is because that every single translation technique has certain characteristic and it will influence to the translation quality. Translation quality here means whether the translated text is accurate, acceptable, readable or not.

\section{Technical Procedure}

Procedure is a way of doing something (Hornby, 2005). The research called technical procedure by reviewing what Anderson (1983) said that procedure is not only getting to know something (know-what) but also how to use something (knowhow) and what Molina and Albir (2002) said that technique is product-oriented to solve the problems. The proposals of technical procedures in using those models are following based on these criteria:

1. Determining the UT (unit translation) which is materialized in unit linguistic such as lexem and word either micro unit or macro unit.

2. After choosing a word, in this case in noun root word of emotional intelligence term as focus of this research, analyze whether the word has equivalence in target language or not. If a word has equivalence in target language, consider whether the word itself acceptable in the target language or not. If it has acceptable equivalence, so the translation technique which is better to choose is establishedequivalent. If it has no acceptable equivalent, move to the second alternative analysis.

3. The second alternative is whether the equivalence having different linguistic level in target text or not. If it has different equivalence in linguistic level or category, so the translation technique which is better to choose is transposition. If it has no different equivalence, move to the third alternative analysis.

4. The third alternative is whether the equivalence using different point of view in target text or not. If it has different point of view in finding out the equivalence, so the translation technique which is better to choose is modulation. If it has no different point of view in finding out the equivalence, move to the fourth alternative analysis.
5. The fourth alternative is the last alternative. It can be used if some previous stages or alternatives cannot be used properly to find out the equivalence. The fourth alternative is related with homophone element or sounds system. It can be started by asking whether the equivalence having similar sounds or phoneme in target text or not. If it has similar sounds or phoneme, so the translation technique which is better to choose is borrowing. It can work either pure borrowing or naturalized borrowing. If it has no similar sounds or phoneme in finding out the equivalence.

\section{Testing the Prototype}

To test the effectivity of the prototype, it will be tested to some translators to translate some documents after the operational procedure was described by the research. Fourth, the researcher conducted and developed semi-structured interview to dig deeper about the advantage and disadvantage of using the prototype to translate. Three experts of translation scholars reviewed the post-prototype after it was tested and commented on its content, appropriateness and clarity. All aspects were combined to classify more specific in using prototype. The prototype was revised to be developed into translation model and the researcher gave the feedback provided by the experts. Finally, the final version of the translation model was approved to be used.

To examine the prototype, the researcher asked some post-graduate students in State Polytechnic of Jakarta to translate some documents by using proposed-translation technique. The techniques are established-equivalent, transposition, modulation, and/or borrowing translation. Based on the operational procedure which has been explained by the researcher, the test-taker tried to use the prototype. According to the test-takers, their ability in translating was improving. Again, the translation quality after it is measured was improving. The improvement of translation quality was approximately $30 \%$ in rate after using the proposed-technique. The scoring system used Nababan model (2012) which assess the translation quality based on three aspects (accuracy, acceptability and readability). 


\section{CONCLUSION}

This research is a development research paradigm in translation modeling based on translation technique and involve quite a bit of morphological approach. The development research based on validating the translation technique analysis translation quality concept. This translation model is developed based on the prototype test in translating texts by the scope of word level. The translation model is combining grammatical concept, translation problem for navigation, and ending at decision making process in choosing suitable translation technique. In the beginning, a translator should analyze the source text features first such as the genre of the text, the target reader of translated-text as macro level until the micro level in syntax aspect. The model is applicable to applying to translation, interpreting, and developing teaching curriculum on translation studies. But it needs to remember that there are broad aspects that need to be developed in the future research such as phrase-based translation by using this model. Again, different text that will be translated may be tested to find out the nature of every single text (genre). As known that genre has special language characteristic and feature.

\section{ACKNOWLEDGEMENT}

The researchers thank to Prof. M. R. Nababan, M. Ed., M.A., Ph.D; Prof. Dr. Djatmika, M. A; Dr. Tri Wiratno, M. A as the supervisors for the assistance and helping in doing the research in giving support when writing this project study.

\section{REFERENCE}

[1] PACTE, "Acquiring translation competence: Hypotheses and methodological problems of a research project". In Beeby, A., Ensinger, D., and Presas, M. (peny.). Investigating Translating., John Benjamins Publishing Company, 2000.

[2] R. T. Bell, Translation and translating: theory and practice, Longman, 1991.

[3] PACTE GROUP, Romero (Principal investigator: Amparo Hurtado Albir). Building a Translation Competence Model In: Alves, F. (ed.). Triangulating Translation: Perspectives in Process Oriented Research (pp. 43-68), John Benjamins, 2003.
[4] B. Mona, "In Other Words: A coursebook on translation, second edition. In M. Baker (Ed.), In Other Words: A coursebook on translation (Second)," 2011. [Online]. Available: https://doi.org/10.1075/target.24.1.19che.

[5] E. Bielsa and S. Bassnett, "Translation in global news. In Translation in Global News," 2008. [Online]. Available: https://doi.org/10.4324/9780203890011.

[6] J. C.Catford, "A Linguistic Theory of Translation. In Language and Language Learning (p. 85)," 1965. [Online]. Available:

http://rahbar.iauq.ac.ir/assets/subdomains/ra hbar/files/93/TheoriesOfTranslation/.

[7] J,House, "Translation Quality Assessment: Past and Present.," Journal of Chemical Information and Modeling, vol. 53, no. 9, 2015.

[8] E. A. Nida, Towards a science of translating, E.J. Brill, 1964.

[9] P. Newmark, "A Textbook of Translation. In Text.," 1988. [Online]. Available: https://doi.org/10.1017/CBO978110741532 4.004.

[10] J. Horbacauskiene, R. Kasperaviciene and S. Petroniene, "Issues of culture specific item translation in subtitling. ScienceDirect, 231(May), 223-228.," 2016.

[11] C. Yan and J. Huang, "The Culture Turn in Translation Studies," p. 487-494, 2014.

[12] T. N. Hidayat and M. Nababan, "The Shift Process in Transitivity System on Obama' s and Trump ' s Inauguration Speech," A Translation Study, vol. 31, no. 2, pp. 211220, 2019.

[13] D. C. Kurniawan, M. Nababan and R. Santosa, "External Conjunction on the Moses Story in Al-Qu'ran Surah Thaha English Translation.," International Journal of Multicultural and Multireligious Understanding, vol. 5, no. 3, p. 246, 2018.

[14] Sriyono and S. Poedjosoedarmo, Penerjemahan Hubungan Konjungtif dalam Teks Hukum Bahasa Inggris ke Dalam Bahasa Indonesia, Gadjah Mada University, 2013.

[15] H. Syarif, "The Expression of English And in the Indonesian Language," vol. 1, no. 1, pp. 151-152, 2011.

[16] M. Baker, In Other Words: A coursebook on translation, second edition. In M. Baker (Ed.), In Other 
Words: A coursebook on translation (Second), Routledge, 2011.

[17] L. Molina and A. H. Albir, "Translation Techniques Revisited: A Dynamic and Functionalist Approach.," Meta: Journal Des Traducteurs, vol. 47, no. 4, p. 498, 2002.

[18] M. Nababan, "Pengembangan model penilaian kualitas terjemahan. Kajian Linguistik Dan Sastra," vol. 24, no. 1, pp. 39-57, 2012.

[19] F. Kusumastuti, "Analisis kontrastif subtitiling dan dubbing dalam film kartun Dora the Explorer seri Wish Upon a Star: Kajian teknik penerjemahan dan kualitas terjemahan," Sebelas Maret University, Surakarta, 2011.

[20] P. Purbasari, "Analisis teknik, metode, dan ideologi penerjemahan dalam subtitle film Jane Eyre versi serial TV BBC," Sebelas Maret University, Surakarta, 2011.

[21] A. K. Maharani, "Analisis teknik penerjemahan dan kualitas terjemahan istilah budaya Tiongkok dari bahasa Mandarin ke bahasa Indonesia dalam buku Stempel Tiongkok: Kumpulan Karya Li Langing dalam Pameran Seni Ukir Stempel dan kaligrafi serta dampak terhadap kualitas terje," in Sebelas Maret University, Surakarta, 2014.

[22] F. Sumarli, "Analisis terjemahan kolokasi budaya spesifik dalam novel the serpent's shadow dan terjemahannya bayangan sang ular karya rick riordan," Sebelas Maret University, Surakarta, 2017.

[23] R. Siregar, "Analisis Penerjemahan dan Pemaknaan Istilah Teknis: Studi Kasus pada Terjemahan Dokumen Kontrak Analisis Penerjemahan dan Pemaknaan Istilah Teknis: Studi Kasus Pada Untuk Memperoleh Gelar Magister Humaniora dalam Program Studi Linguistik pada Sekolah Pa," Sumatera Utara University, Sumatera, 2009.

[24] I. Sukaesih, "Analisis teknik dan kualitas terjemahan istilah manajemen keuangan," Sebelas Maret University, Surakarta, 2015.

[25] Fachrudin, "Analisis Terjemahan istilah Teknik dari bahasa Inggris ke bahasa Indonesia: studi kasus buku Fundamental of Engineering Thermodynamics Karangan Michael J. Moran.," vol. 3, no. 1, 2017.

[26] N, Hasyim, "Analisis terjemahan istilah teknis penelitian dari bahasa Inggris ke bahasa Indonesia: studi kasus buku
Qualitative Data Analysis karangan Matthew dan A. Michel Huberman," Sebelas Maret University, Surakarta, 2015.

[27] Mangatur Nababan; Ardiana Nuraeni; Sumardiono, "Pengembangan model penilaian kualitas terjemahan. Kajian Linguistik Dan Sastra," kajian linguistik dan sastra, vol. 24, no. 1, pp. 39-57, 2012.

[28] J. A. Qinai, "Translation Quality Assessment. Strategies, Parametres and Procedures," Traslation Quality Assessment, vol. 45, no. 3, p. 497, 2000.

[29] T. Volkova, "Translation Model, Translation Analysis, Translation Strategy: an Integrated Methodology. Procedia Social and Behavioral Sciences," Procedia Social and Behavioral Sciences, vol. 154, pp. 301-304, 2014.

[30] A. Karimnia, "Undergraduate translation training: In search of a model.," Procedia Social and Behavioral Sciences, vol. 70, pp. 915-921, 2013.

[31] Liliya A. Nefedova; Irina $\mathrm{N}$. Remkhe, "Towards Cognitive Modelling of the Technical Translation Process," Procedia - Social and Behavioral Sciences, vol. 154, pp. 237-244, 2014.

[32] M. R. Nababan, Aspek teori penerjemahan dan pengalihbahasaan, Surakarta: Universitas Sebelas Maret, 2003.

[33] M. L. Larson, Meaning-Based-TranslationM-L-larson, New York: University Press of America, 1998.

[34] E. A. Nida and C. R. Taber, The theory and practice of translation, New York: E.J. Brill, Leiden, 1982.

[35] J. C. Catford, A Linguistic Theory of Translation. In Language and Language Learning, Edinburgh: Oxford University Press, 1965.

[36] R. T. Bell, Translation and translating: theory and practice, Longman, 1991.

[37] A. Neubert, Competence in language, in languages, and in translation. (cited in Schaffner, C. and Adab, B. (peny.). Developing Translation Competence, Birmingham: Benjamins Translation Library, 2000.

[38] A.S. Horby, Oxford advance learner's dictionary (M. Wehmeier, S., McIntosh, C., Turnbul, J., Ashby (ed.), Britania Raya : Oxford University Press, 2005.

[39] Jean Paul Vinay; Jean Darbelnet, Stylistique comparée du français et de l'anglais. English. Comparative stylistics of French 
and English: A Methodology for Translation, Amsterdam: John Benjamins, 1995.

[40] A. S. Hornby, Oxford advanced learner's dictionary of current English, Inggris: Oxford University Press, 2005.

[41] A. Munif, "Pergeseran dalam penerjemahan klausa pasif dari novel The Lord of the Rings: The Return of the King karya JRR Tolkien oleh Gita Yuliani K," Universitas Sebelas Maret, Surakarta, 2008.

[42] R. Machali, Pedoman bagi penerjemahan., Bandung: Kaifa, 2009.
[43] N. S. Akhiroh, "The Influence of Translation Technique on the Quality of The Translation of International News," Language Circle Journal of Language and Literature, vol. 7, no. 2, pp. 41-51, 2013.

[44] Novalinda, "Teknik, Metode, Ideologi dan Kualitas Terjemahan Cerita Anak Serial Erlangga for Kids," Universitas Sebelas Maret, Surakarta, 2011.

[45] M. Rudolf Nababan, Teori Meneremahkan Bahasa inggris, Yogyakarta: Pustaka Pelajar, 1999. 